\title{
AKSEPTABILITAS DAN SIFAT DAGING ITIK AFKIR YANG DILAKUKAN CURING MENGGUNAKAN EKSTRAK KURKUMIN KUNYIT UNTUK MENGHAMBAT OKSIDASI LEMAK SELAMA PENYIMPANAN
}

\author{
Acceptability and Properties of Rejected-Duck Meat Cured in Turmeric Curcumin Extract to Inhibit Fat \\ Oxidation during Storage
}

\section{Sri Hartati Candra Dewi, Niken Astuti}

Fakultas Agroindustri, Universitas Mercu Buana Yogyakarta

Jl. Wates Km. 10 Yogyakarta 55753

Email: candradewisrihartati@yahoo.co.id

\begin{abstract}
ABSTRAK
Daging itik afkir diperoleh dari itik petelur yang sudah tidak produktif yang berumur 24-26 bulan. Tujuan penelitian ini adalah untuk mengetahui potensi oksidasi dari ekstrak kurkumin dan potensinya dalam curing daging itik afkir terhadap akseptabilitas dan sifat daging selama penyimpanan beku.Materi yang digunakan 36 ekor itik betina afkir dengan kisaran umur 24-26 bulan. Rancangan percobaan yang digunakan adalah rancangan acak lengkap pola faktorial $3 \times 4$ dengan faktor variasi ekstrak kurkumin $0,0 \% ; 0,1 \% ; 0,2 \%$ dan $0,3 \%$ dan lama curing 5, 10 dan 20 menit. Parameter yang diteliti meliputi akseptabilitas daging itik curing ditentukan dengan metode Hedonic Test, kadar air, kadar lemak, asam lemak dan angka peroksida penyimpanan beku selama 8 minggu. Hasil penelitian menunjukkan bahwa daging itik afkir yang paling akseptabel adalah daging itik dengan curing menggunakan $0,3 \%$ ekstrak kunyit dengan lama curing selama 10 menit. Penambahan ekstrak kurkumin kunyit pada daging itik afkir mampu menghambat peroksidasi asam lemak sekitar 39,55\% pada penyimpanan beku selama lima minggu. Kadar air dan lemak menunjukkan perbedaan yang tidak nyata. Namun asam lemak bebas mengalami kenaikan yang signifikan sampai minggu ke 5. Angka peroksida meningkat sampai minggu kelima sebesar 39,55 m.eq, kemudian menurun. Dari penelitian ini dapat disimpulkan bahwa akseptabilitas terbaik menggunakan ekstrak kurkumin $0,3 \%$ dengan lama curing 10 menit, pada penyimpanan beku selama 8 minggu.
\end{abstract}

Kata kunci:Daging itik afkir, antioksidan kurkumin, akseptabilitas dan kualitas daging

\begin{abstract}
Rejected-duck meat was obtained from old laying duck that unproductive aged 24-26 months. The purpose of this study was to determine the oxidation potential of curcumin extract and its potential in curing rejects the acceptability of duck meat and meat properties during frozen storage. The material used was 36 female rejected-duck the age range $24-26$ months. The experimental design used was completely randomized design with $3 \times 4$ factorial variation. This factor of $0.0 \% ; 0.1 \% ; 0.2 \%$ and $0.3 \%$ curcumin extract and the curing time 5, 10 and 20 minutes. The parameters examined included the acceptability of duck meat cured was determined by the method of Hedonic Test, moisture content, fat content, fatty acids and peroxide value of frozen storage for 8 weeks. The results showed that duck meatwas acceptable salvage most of duck meat with curing using $0.3 \%$ turmeric extract with a curing time for 10 minutes. The addition of curcumin turmeric extract the meat of rejected-ducks could inhibit fatty acid peroxidation approximately $39.55 \mathrm{~m} . \mathrm{eq}$ in frozen storage for five weeks. Water content and fat showed no real difference. However, free fatty acids increased significantly up to 5 weeks. Peroxide value increased until the fifth week of $39.55 \%$, and then decreased. From this study it can be concluded that the best use extract acceptability of curcumin $0.3 \%$ with long curing 10 minutes, the frozen storagefor8weeks.
\end{abstract}

Keywords: Rejected- ducks meat, curcumin, antioxidant, acceptability and quality of the meat 


\section{PENDAHULUAN}

Daging itik afkir diperoleh dari itik betina (petelur) yang sudah tidak produktif. Jumlah daging itik yang ada di pasaran masih sangat terbatas, biasanya selain berasal dari betina afkir (54,35\%), juga dari pejantan afkir sebanyak 35,41\%, jantan dan betina muda sebanyak 18\%(Hardjosworo, 2001). Jumlah produksi daging itik mencapai 30.053 ton, dengan angka pertumbuhan sekitar $3,08 \%$ per tahun (Anonim, 2013). Kendala yang dihadapi dalam penggunaan daging itik afkir adalah tekstur liat dan kadar lemak lebih tinggi dari ayam pedaging. Kadar lemak daging itik mencapai $1,84 \%$, sedangkan daging ayam 1,05\% (Ali dkk., 2007). Lebih lanjut disebutkan bahwa asam lemak tak jenuh (ALTJ) lebih dari $60 \%$ dari total asam lemak, mengakibatkan daging itik mudah teroksidasi yang dapat menurunkan flavor, zat gizi dan menimbulkan zat yang bersifat toksik.Toksisitas zat hasil oksidasi lemak dikarenakan pembentukan radikal bebas atau ROS (Reactive Oxygen Spesies) yang bertanggungjawab terhadap kerusakan jaringan akibat peroksidasi lemak, kerusakan DNA dan protein (Stohs, 1995).Menurut Baggio dan Bragagnolo (2006), selama penyimpanan daging dapat mengalami oksidasi yang dipicu adanya panas, sinar, logam dan oksigen menghasilkan ROS yang dapat memicu timbulnya penyakit degeneratif seperti kardiovaskular dan penuaan dini. Untuk menghambat kerusakan tersebut, diperlukan zat yang dapat mencegah atau memperlambat terjadinya oksidasi yaitu antioksidan.

Antioksidan yang digunakan dalam bahan makanan umumnya antioksidan sintetik seperti BHT (Butylated Hydroxy Toluene) dan BHA (Butylated Hydroxy Anisole). Namun penggunaan antioksidan alami lebih disukai, karena diyakini aman bagi kesehatan. Hasil isolasi senyawa kurkuminoidoleoresin kunyit yaitu kurkumin, demetoksikurkumin, Bis-demetoksikurkumin diketahui mampu menghambat peroksidasi asam lemak (linoleat) (Jayaprakasha dkk.,2006). Hasil penelitian Wahyudi (2006) menunjukkan bahwa konsentrasi paling efektif untuk kurkumin adalah 200 ppm dengan pembanding bilangan peroksida kontrol pada hari ke-8. Selain antioksidan, kurkumin bermanfaat bagi kesehatan karena dapat berperan sebagai hipokolesterolemik dan hipoglikemik (Fujiwara dkk., 2008) serta hipolipidemik dan nephroprotective (Shishu dan Maheshwari, 2010). Namun kurkumin berwarna kuning, dan dapat meningkatkan flavor, sehingga dapat mempengaruhi akseptabilitas produk seperti daging itik yang dilumuri ekstraknya.

Penelitian curing daging itik dilakukan pada daging itik yang sebelum disimpan dalam freezer. Hasil penelitian menunjukkan penyimpanan dalam freezer mampu mempertahankan sifat inderawi selama 8 minggu dan meningkatkan keempukan daging sapi(Candra Dewi, 2011). Ali dkk. (2007) menunjukkan pelunakan daging itik dari 3,84 $\mathrm{kg} / \mathrm{cm} 2$ menjadi $3,12 \mathrm{~kg} / \mathrm{cm} 2$ selama 7 hari pada suhu $4^{\circ} \mathrm{C}$. Permasalahannya adalah penyimpanan maupun pengolahan daging itiktidak lepas dari kondisi kontak dengan panas, udara, dan sinar sehingga memungkinkan oksidasi lemak (Baggio dan Bragagnolo, 2006). Oleh karena itu penyimpanan daging itik afkir curing dalam freezer selain menghambat oksidasi lemak, sekaligus diharapkan melunakkan daging itik afkir. Tujuan penelitian ini adalah untuk mengetahui potensi antioksidasi dari ekstrak kurkumin dalam daging itik afkir curing dalam dan menghasilkan daging itik curing dengan akseptabilitas tinggi.

\section{METODE PENELITIAN}

\section{Bahan}

Bahan yang digunakan untuk penelitian adalah daging itik afkir yang diperoleh dari peternak itik di desa Argomulyo, Sedayu, Bantul, Yogyakarta. Itik betina afkir sebanyak 36 ekor, dengan kisaran umur 24-26 bulan. Rimpang kunyit (Curcuma domestica Val.) sebagai sumber antioksidan alami dibeli dari pasar lokal di wilayah Yogyakarta. Rimpang kunyit yang sudah mempunyai cabang disortasi, kemudian dikupas dan dicuci. Ekstraksi kurkumin menggunakan cara maserasi (Marsono dkk., 2005). Analisis pada bahan dasar (daging itik) meliputi: kadar air dengan metode gravimetri (AOAC, 1990), lemak dengan ekstraksi menggunakan Soxhlet (AOAC, 1990), tingkat oksidasi lipida (lemak) berdasarkan angka peroksida dan asam lemak pada daging itik segar ditentukan menggunakan metode titrasi sebagai asam oleat (Apriyantono dkk., 1989). Bahan-bahan kimia untuk analisis semuanya dengan kualifikasi pro analysis dari Merck.

\section{Cara Penelitian}

Penelitian ini terdiri dari 5 tahap yaitu: 1) preparasi ekstrak kurkumin kunyit, evaluasi kadar kurkumin dan aktivitas antioksidasi ekstrak kurkumin kunyit, 2) proses curing daging itik segar dengan ekstrak kurkumin kunyit berdasarkan rasio daging itik/ekstrak kurkumin kunyit serta lama curing, 3) menentukan akseptabilitas daging itik curing secara organoleptik berdasarkan uji inderawi, 4) penyimpanan daging itik pada freezer, 5) evaluasi efek curing daging itik dalam ekstrak kurkumin kunyit terhadap tingkat oksidasi lemak berdasarkan angka peroksidaselama penyimpanan. Dari tahap yang dilakukan akan diperoleh kondisi curing daging itik yang dapat menghasilkan daging curing dengan akseptabilitas tinggi. 


\section{Preparasi Ekstrak Kurkumin Kunyit}

Proses ekstraksi kunyit dilakukan dengan maserasi dengan alkohol (Marsono dkk., 2005). Rimpang kunyit dicuci, dikupas, diiris dengan ketebalan $1 \mathrm{~mm}$. Selanjutnya diblansing dengan perebusan selanjutnya dibekukan. Sebanyak 300 g sampel dimasukkan ke dalam akuades mendidih $600 \mathrm{ml}$ selama 5 menit, ditiriskan selama 15 menit, dan dikemas dalam kantung plastik untuk disimpan dalam freezer pada suhu $-12^{\circ} \mathrm{C}$ selama 24 jam. Sampel dithawing selama 30 menit, kemudian diatur di atas nampan dan dimasukkan pengering kabinet pada suhu $57^{\circ} \mathrm{C}$ sampai kadar air sekitar 10\%. Kunyit kering, diblender, diayak dengan ayakan 35 mesh, sehingga dihasilkan kunyit bubuk. Ekstraksi kunyit menggunakan cara macerasi dimodifikasi yaitu kunyit bubuk $15 \mathrm{~g}$ dimasukkan erlenmeyer $250 \mathrm{ml}$ ditambah alkohol 80 $\%$ sebanyak $135 \mathrm{ml}$, ditutup aluminium foil, diaduk dengan shaker selama 60 menit, kemudian didiamkan selama 24 jam. Selanjutnya disaring dengan kertas saring Whatman no. 41, sehingga dihasilkan ekstrak kunyit. Ethanol diuapkan menggunakan evaporator vakum pada suhu $40^{\circ} \mathrm{C}$. Ekstrak yang diperoleh digunakan untuk curing daging itik. Ekstrak kurkumin hasil ekstraksi menggunakan maserasi dianalisis kadar air dengan metode gravimetri (AOAC, 1990), kurkumin dengan spektrometri (Sudibyo, 1996). Sampel sebanyak $1 \mathrm{~g}$ dihancurkan dan $10 \mathrm{ml}$ alkohol. Larutan tersebut dicampur sampai homogen selama 1 menit dan didiamkan selama 1 jam, kemudian disaring. Larutan disentrifus selama 10 menit dan ditera absorbansinya pada panjang gelombang $431 \mathrm{~nm}$. Kadar kurkumin dihitung menggunakan kurva standar kurkumin.

\section{Evaluasi Aktivitas Antioksidasi}

Evaluasi aktivitas antioksidasikurkumin mengacu padaHu dkk. (2003) menggunakan metode DPPH (1,1Diphenyl-2-picrylhydrazil) untuk menghitung Radical Scavenging Activity (RSA). DPPH dilarutkan dalam etanol absolut, sehingga konsentrasi yang dihasilkan $6 \times 10^{-5}$ M. Larutan DPPH disimpan dalam refrigerator sebelum digunakan. Larutan sampel $(0,1 \mathrm{ml})$ ditambahkan dalam $29 \mathrm{ml}$ larutan DPPH. Absorbansi dibaca menggunakan spektrofotometer pada panjang gelombang $517 \mathrm{~nm}$. Dibuat blanko dengan perlakuan yang sama tanpa sampel. Sampel diinkubasi dan absorbansi diukur dari nol sampai dengan 120 menit, dengan interval waktu 15 menit. Radical Scavenging Activity (RSA) dihitung berdasarkan perubahan absorbansi setelah 30 menit atau ketika perubahan absorbansi sudah tidak nyata, dengan perhitungan :

$$
\% \operatorname{RSA}=\left(1-\mathrm{A}_{\mathrm{T}} / \mathrm{A}_{\mathrm{o}}\right) \times 100 \%
$$

Keterangan : $\mathrm{A}_{\mathrm{T}}$ : absorbansi sampel dengan waktuinkubasi30 menit Ao: absorbansi sampel dengan waktu nol (sebelum inkubasi).

\section{Curing Daging Itik Segar Berdasarkan Rasio Ekstrak Kurkumin dan Daging Itik Segar Kunyit dan Lama Curing}

Daging itik segar tanpa tulang dipotong dengan ukuran tertentu yang homogen (hasil orientasi). Proses curing daging itik dilakukan dengan cara mencampur ekstrak kurkumin kunyit dengan daging itik segar. Jumlah ekstrak kurkumin kunyit yang ditambahkan pada daging itik adalah : $0,0 \%$; $0,1 \% ; 0,2 \%$ dan $0,3 \%$ (mL ekstrak kurkumin/berat daging itik), sedangkan lama curingadalah 5; 10; 20 menit. Semua sampel daging itik curing dianalisis kadar air dengan metode gravimetri (AOAC, 1990), lemak dengan destilasi Soxhlet (AOAC, 1990), dan angka peroksida (Apriyantono dkk., 1989).

\section{Uji Akseptabilitas Daging Itik Curing}

Untuk menentukan akseptabilitas terhadap daging itik curing dengan variasi jumlah ekstrak kurkumin dan lama curing, maka dilakukan uji kesukaan daging mentah terhadap bau, warna, tekstur, flavor menggunakan metode Hedonic Test (Krammer dan Twigg, 1970). Pengujian ini harus dilakukan mengingat penambahan ekstrak kunyit akan mempengaruhi sifat fisik daging terutama pada warna dan bau, sehingga diperkirakan akan mempengaruhi penerimaan terhadap daging itik. Data hasil pengujian secara inderawi diolah secara statistik untuk mendapatkan daging curing dengan akseptabilitas tinggi. Dari hasil pengujian akan diperoleh konsentrasi dan lama curing yang tepat untuk dilanjutkan dengan perlakuan penyimpanan beku.

\section{Penyimpanan Daging Itik Curingdengan Akseptabilitas Tinggi dalam Freezer}

Penyimpanan daging itik dengan pendinginan mengacu pada metode yang dilakukan oleh Candra Dewi (2010) dan Candra Dewi (2011). Daging yang telah dicampur dengan ekstrak kurkumin masing-masing dikemas dalam plastik polietilen $0,5 \mathrm{~mm}$. Sampel disiapkan dengan beberapa kemasan sampel untuk digunakan sampling secara periodik selama 8 minggu penyimpanan beku pada suhu $-18^{\circ} \mathrm{C}$. Sampel yang diambil pada setiap seminggu sekali dianalisis kadar air, lemak, asam lemak, dan angka peroksida menggunakan Test Zwick.Dari hasil penelitian diperoleh kondisi curing daging itik yang tepat yang dapat menghasilkan daging itik curing dengan akseptabilitas tinggi serta lama penyimpanan daging itik curing dengan sifat kimia yang masih dapat diterima.

Rancangan percobaan yang digunakan adalah Rancangan Acak Lengkap pola faktorial $4 \times 3$ dengan faktor yaitu variasi ekstrak kurkumin/berat daging $(0,0 \% ; 0,1 \% ; 0,2 \%$ dan $0,3 \%)$ dan lama curing $(5 ; 10 ; 20$ menit), dengan 3 ulangan. Untuk menentukan adanya perbedaan antar perlakuan digunakan 
uji F, selanjutnya beda nyata antar sampel ditentukan dengan Duncan's Multiples Range Test (DMRT) (Gacula dan Singh, 1984).

\section{HASIL DAN PEMBAHASAN}

Kunyit digunakan sebagai sumber antioksidan untuk menghambat oksidasi lemak pada daging itik afkir, karena mengandung senyawa kurkumin. Menurut Fujiwara dkk. (2008), kurkumin sangat potensial sebagai antioksidan. Sifat antioksidatif tersebut terkait dengan struktur difenol dari kurkumin (Pfeiffer dkk., 2003). Kemampuan antioksidan dalam menghambat reaksi oksidasi melalui beberapa mekanisme seperti mereduksi radikal bebas hasil oksidasi lemak, menangkap oksigen yang dibutuhkan untuk oksidasi (oxygen scavenger), chelating agent dan mendekomposisi peroksida hasil pemecahan lemak. Senyawa fenolik termasuk dalam chain breaking antioxidant, karena kemampuannya menangkap radikal bebas(Bombardelli dan Morazzoni, 1993 dalam Benavente-Garcia dkk., 1997). Aktivitas antioksidan kunyit dalam menghambat pembentukan peroksida, menunjukkan hasil yang nyata setara dengan temulawak maupun jahe (Septiana dkk., 2006). Hasil analisis kurkumin dalam kunyit segar dan ekstrak kunyit serta aktivitas antioksidasi dalam kemampuan menangkap radikal bebas dapat dilihat pada Tabel 1.

Tabel 1. Hasil analisis kadar kurkumin dan air

\begin{tabular}{lccc}
\hline & $\begin{array}{c}\text { Kurkumin } \\
(\%)\end{array}$ & $\begin{array}{c}\text { Air } \\
(\%)\end{array}$ & $\begin{array}{c}\text { RSA (Radical } \\
\text { Scavenging } \\
\text { Activity) \%* }\end{array}$ \\
\hline Kunyit segar & 0,070 & 85,54 & 27,57 \\
Ekstrak kunyit & 0,245 & 22,73 & 8,04 \\
BHT & - & - & 8,36 \\
\hline
\end{tabular}

* Berat sampel $1 \mathrm{~g}(\mathrm{bk})$, kecuali BHT 0,1 g(bk)

Kadar air kunyit segar sekitar 85,23\%, hasil penelitian ini menunjukkan bahwa kondisi kunyit masih segar. Kadar air ekstrak kunyit sekitar 22,73\%, oleh karena itu berdasarkan jumlah solid, kadar kurkumin ekstrak kunyit lebih besar daripada kunyit segar.

\section{Aktivitas Antioksidasi Kunyit Segar dan Ekstrak Kunyit}

Aktivitas antioksidasi kunyit dan ekstraknya dinyatakan sebagai kemampuan menangkap radikal bebas DPPH atau dinyatakan sebagai persentase Radical Scavenging Activity (RSA). Data pada Tabel 1 tersebut menunjukkan bahwa ekstrak kunyit memiliki aktivitas antioksidasi yang setara dengan BHT. Hasil ini sesuai dengan kandungan kurkumin dalam ekstrak yang lebih besar daripada kunyit segar. Menurut Hu dkk. (2003), aktivitas antioksidasi kunyit ditentukan oleh kandungan senyawa kurkuminnya. Kandungan kurkumin ekstrak kunyit lebih besar daripada kunyit segar (Tabel 1). Oleh karena itu aktivitas antioksidasinya lebih tinggi dibandingkan kunyit segar. Aktivitas antioksidasi kunyit juga dapat dilihat pada Gambar 1.

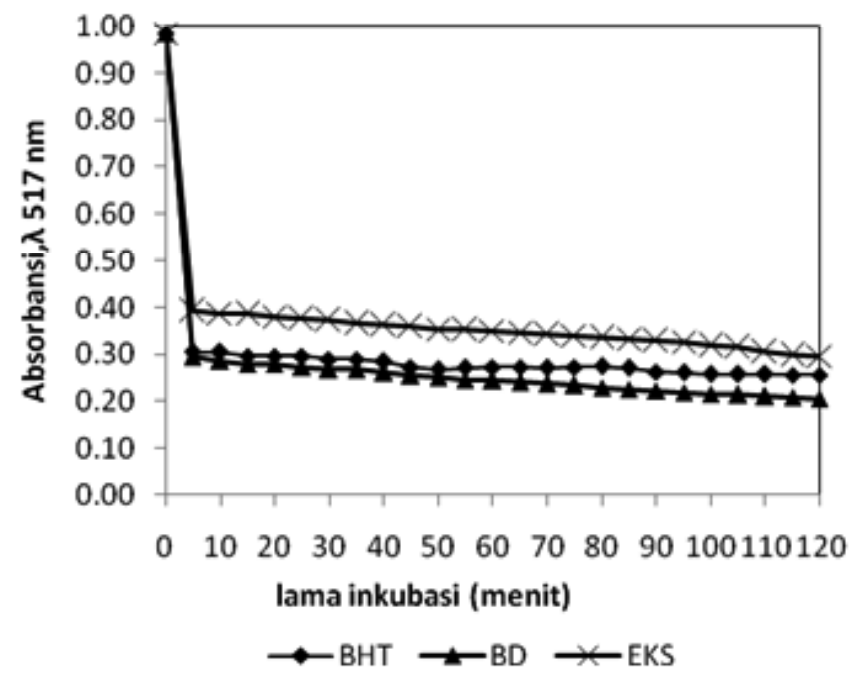

Gambar 1. Aktivitas antioksidasi kunyit dan ekstraknya

(BHT=Butylated Hydroxytoluent, $\mathrm{BD}=$ Bahan Dasar, EKS= ekstrak).

Gambar 1 menunjukkan bahwa intensitas warna ungu DPPH pada $\lambda 517 \mathrm{~nm}$ semakin turun dengan semakin lama waktu inkubasi. Artinya bahwa sebagian radikal DPPH sudah ditangkap oleh antioksidan kurkumin. BHT dan ekstrak kunyit mampu menurunkan jumlah radikal DPPH lebih tinggi dibandingkan kunyit segar. Oleh karena itu tepat apabila ekstrak kunyit digunakan sebagai sumber antioksidan alami untuk mencegah oksidasi lemak pada daging itik afkir.

\section{Optimasi Kondisi Curing dan Hasil Uji Akseptabilitas Daging Itik Afkir Curing}

Akseptabilitas daging itik afkir curing ditentukan berdasarkan kesukaan terhadap sifat inderawi yaitu bau, warna, tekstur daging itik afkir. Hasil pengujian inderawi disajikan padaTabel 2. Nilai atau angka kesukaan yang semakin besar menunjukkan semakin kurang disukai.

Bau. Hasil pengujian inderawi menunjukkan bahwa bau daging itik afkir setelah curing dengan ekstrak kunyit $0,0 \% ; 0,1 \% ; 0,2 \%$ dan $0,3 \%$ selama 5 menit, 10 menit dan 20 menit berbeda nyata dengan kontrol (tanpa curing). Daging itik curing lebih disukai baunya daripada tanpa curing. Ratarata nilai kesukaan dengan skor 3 termasuk disukai, skor semakin tinggi bau semakin tidak disukai.Pada penambahan ektrak 0,3\% dengan lama curing 10 dan 20 menit mempunyai 
nilai skor paling rendah, artinya mempunyai bau yang lebih disukai karena bau amis berkurang dibandingkan yang tanpa curing. Hal ini disebabkan penambahan ekstrak kunyit dapat mengurangi bau amis daging itik, sehingga lebih disukai. Keadaan ini menguntungkan karena dapat dipakai sebagai dasar penggunaan ekstrak kunyit untuk menghambat oksidasi lemak.

Warna. Nilai warna daging yang tinggi menunjukkan warna semakin merah. Warna daging itik merah, setelah curing menjadiagakkekuningan. Hasil penelitianmenunjukkan warna daging itik curing yang berwarna merah muda kekuningan lebih disukai. Daging curing dengan 0,2\% dengan lama curing 5 menit mempunyai nilai warna paling rendah dibanding yang lainnya. Daging curing dengan ekstrak kunyit 0,2\% dan 0,3\% pada lama curing 10 dan 20 menit mempunyai nilai warna yang relatif lebih rendah dibanding $0,1 \%$ pada lama curing 5 , 10 dan 20 menit. Dimana pada ektrak kunyit $0,1 \%$ pada lama curing 5, 10 dan 20 menit mempunyai nilai warna lebih tinggi dan tidak berbeda dengan warna daging itik alami. Berkaitan dengan warnanya, menurut Ali dkk. (2007), warna daging itik nilai redness sangat tinggi, sedangkan lightness atau kecerahan sangat rendah. Ektrak kunyit memberikan perbaikan warna daging dari warna merah menjadi merah muda kekuningan, sehingga dari penampilan menjadi lebih menarik.

Tekstur. Secara inderawi tekstur daging itikdapat dinilai dengan indera peraba dengan tangan (finger feel). Hasil penelitian menunjukkan bahwa tekstur berbeda tidak nyata antar perlakuan. Tekstur daging itikditentukan berdasarkan kekerasannya (hardness) atau kelunakannya (softness). Hal ini disebabkan karena curing tidak dimaksudkan untuk melunakkan dan hanya bertujuan untuk menambahkan antioksidan pada daging itik, sehingga tidak terjadi perubahan tekstur akibat curing.
Kesukaan Keseluruhan. Hasil analisis statistik terhadap kesukaan keseluruhan daging itik afkir curing menunjukkan perbedaan yang nyata. Tingkat kesukaan sampel hampir sama dengan kategori suka, kecuali sampel kontrol (tanpa curing) dan sampel dengan curing $0,1 \%$ ekstrak kunyit selama 5 menit. Berdasarkan intensitas kesukaan terhadap bau, warna dan tekstur, secara keseluruhan daging itik afkir curing yang paling disukai adalah daging curing dengan penambahan ekstrak kunyit 0,2\% dan lama curing 5 menit serta penambahan ekstrak kunyit 0,3\% dengan lama curing 10 menit. Daging itik curing disukai karena bau amis berkurang, warna kuning cerah dan teksturnya kukuh. Namun berdasarkan aktivitas antioksidasinya, maka digunakan curing selama 10 menit dengan penambahan ekstrak $0,3 \%$.

\section{Perubahan Kadar Lemak Daging Itik Afkir Curing selama Penyimpanan}

Perlakuan curing daging itik menggunakan ekstrak kunyit diharapkan mampu menurunkan tingkat oksidasi lemak selama penyimpanan dan penanganan. Hasil analisis terhadap lemak daging itik selama penyimpanan disajikan pada Tabel 3 .

Berdasarkan hasil analisis menunjukkan bahwa kadar air dan lemak daging itik tidak mengalami perubahan selama penyimpanan. Kadar air daging itik sekitar 72,30\% dan lemak 5,15\%. Menurut Ali dkk. (2007) kadar air dan lemak itik masing-masing76,41 $\pm 0,70 \%$ dan $1,84 \pm 0,08 \%$. Kadar lemak daging itik hasil penelitian lebih tinggi. Faktor yang mempengaruhi kadar lemak dan asam lemak dari daging itik adalah jenis itik, nutrisi dalam pakan dan umur itik. Jumlah lemak dalam daging itik dapat mencapai 6,08\% (Baeza, 2006).

Perubahan kadar lemak daging itik curing selama penyimpanan dan kadar air daging itik dapat dilihat pada

Tabel 2. Hasil uji akseptabilitas daging itik afkir curing

\begin{tabular}{|c|c|c|c|c|c|}
\hline Lama curing (menit) & Persentase ekstrak kunyit* & $\mathrm{Bau}^{*}$ & Warna* & Tekstur ${ }^{\mathbf{n s}}$ & Keseluruhan* \\
\hline Kontrol (tanpa curing) & - & $4,15^{\mathrm{bc}}$ & $3,80^{\mathrm{b}}$ & 3,95 & $4,10^{c}$ \\
\hline \multirow[t]{4}{*}{5} & 0,1 & $3,70^{\mathrm{abc}}$ & $3,65^{\mathrm{b}}$ & 4,10 & $3,50^{\mathrm{abc}}$ \\
\hline & 0,2 & $3,30^{\mathrm{abc}}$ & $2,40^{\mathrm{a}}$ & 3,25 & $3,05^{\mathrm{a}}$ \\
\hline & 0,3 & $3,20^{\mathrm{ab}}$ & $3,05^{\mathrm{ab}}$ & 3,40 & $3,30^{\mathrm{abc}}$ \\
\hline & 0,1 & $4,40^{\mathrm{c}}$ & $3,45^{\mathrm{b}}$ & 4,40 & $4,05^{\mathrm{bc}}$ \\
\hline \multirow[t]{3}{*}{10} & 0,2 & $3,05^{\mathrm{ab}}$ & $3,30^{\mathrm{ab}}$ & 3,35 & $3,30^{\mathrm{abc}}$ \\
\hline & 0,3 & $2,90^{\mathrm{a}}$ & $3,00^{\mathrm{ab}}$ & 4,00 & $3,10^{\mathrm{a}}$ \\
\hline & 0,1 & $3,45^{\mathrm{abc}}$ & $3,60^{\mathrm{b}}$ & 3,80 & $3,50^{\mathrm{abc}}$ \\
\hline \multirow[t]{2}{*}{20} & 0,2 & $3,60^{\mathrm{abc}}$ & $3,65^{\mathrm{b}}$ & 3,65 & $3,70^{\mathrm{abc}}$ \\
\hline & 0,3 & $2,95^{\mathrm{a}}$ & $3,00^{\mathrm{ab}}$ & 3,70 & $3,15^{\mathrm{ab}}$ \\
\hline
\end{tabular}

ns : tidak berbeda nyata

*superskrip pada kolom yang sama menunjukkan berbeda nyata $(\mathrm{P} \geq 0,05)$ 
Tabel 3. Selama penyimpanan dalam freezer, lemak tidak mengalami penurunan yang nyata. Hal ini sesuai dengan penelitian sebelumnya, karena lemak dalam keadaan beku sehingga sedikit mengalami kerusakan. Namun asam lemak bebas mengalami kenaikan yang signifikan sampai minggu ke 5 .

Hasil ini senada dengan pola perubahan angka peroksida. Menurut Fennema (1985), oksidasi asam lemak berawal dari inisiasi asam lemak membentuk radikal bebas, kemudian oksidasi menghasilkan peroksida. Selanjutnya peroksida mengalami peruraian membentuk aldehid yang menyebabkan off-flavour. Hasil penelitian Ali dkk. (2007) menunjukkan bahwa daging itik segar yang disimpan selama satu hari pada suhu $-4^{\circ} \mathrm{C}$ angka peroksidanya sudah mencapai $35,66 \mathrm{~m} . \mathrm{eq} /$ kg bahan, setelah 1 minggu angka peroksida 31,48 m.eq/ $\mathrm{kg}$ bahan. Artinya bahwa penambahan ekstrak kunyit pada daging itik pada satu mingu pertama mampu menghambat kenaikan angka peroksida sekitar 35,58\%. Dari penelitian ini dapat dikatakan bahwa curing daging itik menggunakan ekstrak kunyit mampu menghambat peroksidasi lemak 39,55 $\mathrm{m} . \mathrm{eq} / \mathrm{kg}$ bahan.

Tabel 3. Profil lemak pada daging itik selama penyimpanan

\begin{tabular}{|c|c|c|c|c|}
\hline $\begin{array}{l}\text { Penyimpanan } \\
\text { minggu ke- }\end{array}$ & $\operatorname{Air}(\%)^{n s}$ & Lemak $(\%)^{\text {ns }}$ & $\begin{array}{l}\text { Asam lemak } \\
\text { bebas }(\%)^{*}\end{array}$ & $\begin{array}{c}\text { Angka* } \\
\text { Peroksida (m.eq } \mathrm{O}_{2} / \mathrm{kg} \text { daging) }\end{array}$ \\
\hline 0 & 72,30 & 5,15 & $0,38^{\mathrm{ab}}$ & $7,77^{\mathrm{a}}$ \\
\hline 1 & 72,75 & 4,31 & $0,43^{\mathrm{b}}$ & $20,28^{b}$ \\
\hline 2 & 71,90 & 5,36 & $0,46^{\mathrm{b}}$ & $37,27^{\text {de }}$ \\
\hline 3 & 72,32 & 5,31 & $0,37^{\mathrm{ab}}$ & $36,02^{\text {cde }}$ \\
\hline 4 & 72,00 & 4,69 & $0,43^{\mathrm{b}}$ & $33,52^{\text {cde }}$ \\
\hline 5 & 71,25 & 5,48 & $0,43^{\mathrm{b}}$ & $39,55^{\mathrm{e}}$ \\
\hline 6 & 72,30 & 5,83 & $0,32^{\mathrm{a}}$ & $30,32^{\mathrm{cd}}$ \\
\hline 7 & 72,37 & 5,02 & $0,39^{\mathrm{ab}}$ & $28,01^{\mathrm{c}}$ \\
\hline 8 & 71,59 & 5,42 & $0,37^{\mathrm{ab}}$ & $33,82^{\text {cde }}$ \\
\hline
\end{tabular}

ns : tidak berbeda nyata

* superskrip pada kolom yang sama menunjukkan berbeda nyata $(\mathrm{P} \geq 0,05)$

\section{KESIMPULAN}

Penambahan ekstrak kurkumin kunyit pada daging itik afkir mampu menghambat peroksidasi asam lemak sekitar $39,55 \mathrm{~m} . e q / \mathrm{kg}$ bahan penyimpanan beku selama lima minggu. Daging itik afkir yang paling akseptabel adalah daging itik dengan curing menggunakan 0,3\% ekstrak kunyit dengan lama curing selama 10 menit.

\section{UCAPAN TERIMA KASIH}

Penulis mengucapkan terima kasih kepada Direktorat Jenderal Pendidikan Tinggi yang telah memberikan bantuan dana penelitian melalui Program Hibah Bersaing Tahun Anggaran 2012-2013.

\section{DAFTAR PUSTAKA}

Ali. M.S., Kang, G.H., Yang, H.S. Jeong, J.Y., Hwang, Y.H., Park, G.B. dan Joo, S.T. (2007). A Comparison of meat characcteristics between duck and chicken breast. AsianAustralasian Journal Animal Science 20: 1002-1006.
Anonim (2013). Produksi daging itik menurut provinsi 20092013. Badan Statistik Nasional. http://www.pertanian. go.id/pdf-eisNAK2013/Prod_DagingItik_Prop_2013. pdf. [15 Mei 2014].

AOAC (1990). Officials Methods of Analysis Association Official Agricultural Chemistry. Washington D.C.

Apriyantono, A., Fardiaz, D., Puspitasari, N.L., Sedarnawati dan Budiyanto, S. (1989). Analisis Pangan. Pusat Antar Universitas Pangan dan Gizi. Institut Pertanian Bogor, Bogor.

Baggio, S.R. dan Bragagnolo, N. (2006). Cholesterol oxide, cholesterol, total lipid and fatty acid content in processed meat products during storage. Swiss Society of Food Science and Technology 39: 513-520.

Benavente-Garcia, O., Castillo, J., Marin, F.R., Ortuno, A.dan Del Rio, J.A. (1997). Uses and properties of citrus flavonoid. Journal of Agricultural and Food Chemistry 12(40): 4505-4514.

Candra Dewi, S.H. (2010). Sifat Fisik Daging Sapi pada Lama Penyimpanan yang Berbeda. Laporan Penelitian. Universitas Mercu Buana, Yogyakarta. 
Candra Dewi, S.H. (2011). Populasi Mikroba dan Sifat Fisik Daging Sapi Beku pada Lama Penyimpanan yang Berbeda. Laporan Penelitian. Universitas Mercu Buana, Yogyakarta.

Fennema, O.R. (1996). Food Chemistry. Marcell Dekker Inc. New York.

Fujiwara, H., Hosokawa, M., Zhou, X., Fujimoto, S., Fukuda, K., Toyoda, K., Nishi, Y., Fujito, Y., Yamada, K., Yamada, Y., Seino, Y. dan Inagaki, N. (2008). Curcumin inhibits glucose production in isolated mice hepatocytes. Diabetes Research and Clinical Practice 80: 188-191.

Gacula, M.C. dan Singh, J. (1984). Statistical Methods in Food and Consumer Research. Academic Press, Inc. Orlando. San Diego. New York. London.

Hardjosworo (2001). Ternak Itik. Penebar Swadaya, Jakarta.

Hu, Q., Hu, Y. dan Xu, J. (2003). Evaluation of antioxidant potential of Aloe vera (Aloe barbadensis Miller) extracts. Journal of Agricultural and Food Chemistry 51(26): 7788-7791.

Jayaprakasha, G.K, Jaganmohan, R.L. dan Sakariah, K.K. (2006). Antioxidant activities of curcumin, demethoxycurcumin and bisdemethoxycurcumin. Food Chemistry 98: 720-724.

Krammer, A.A. dan Twigg, B.A. (1970). Fundamental of Quality Control for the Food Industry. The AVI Publishing Company, Inc. Westport. Connecticut.
Marsono, Y., Safitri, R. dan Noor, Z. (2005). Antioksidan dalam Kacang-kacangan: Aktivitas dan Potensi serta Kemampuannya Menginduksi Pertahanan Antioksidan pada Model Hewan percobaan. Laporan Penelitian Hibah Bersaing XII. Fakultas Teknologi Pertanian. Universitas Gadjah Mada, Yogyakarta.

Pfeiffer, F., Hohle, S.,Solyom, A.M. dan Metzler, M. (2003). Studies on the stability of turmeric constituents. Journal of Food Engineering 56: 257-259.

Septiana, A.T., Mustaufik, Dwiyanti, H., Muchtadi, D., Zakaria, F. dan Ola, M.M. (2006). Pengaruh spesies Zingiberaceae (jahe, temulawak, kunyit, dan kunyit putih) dan ketebalan irisan sebelum pengeringan terhadap kadar dan aktivitas antioksidan ekstrak aseton yang dihasilkan. Majalah Ilmu dan Teknologi Pertanian 26(2): 69-74.

Shishu dan Maheshwari, M. (2010). Comparative bioavailability of curcumin, turmeric and biocurcumax ${ }^{\mathrm{TM}}$ in traditional vehicles using non-everted rat intestinal Sac model. Journal of Functional Foods 2: 60-65.

Stohs, S.J. (1995). The role of free radicals in toxicity and desease. Journal Basic Clinical Physiological and Farmacology 6: 205-208.

Sudibyo, M. (1996) Penentuan kadar kurkuminoid secara KLT-Densitometri. Buletin Ikatan Sarjana Farmasi Indonesia 2: 11-21. 